\title{
Spotlight on chimeric antigen receptor engineered $T$ cell research and clinical trials in China
}

\author{
Can Luo ${ }^{\dagger}$, Jianshu Wei \& Weidong Han ${ }^{*}$ \\ Institute of Basic Medicine/Bio-therapeutic Department, Chinese PLA General Hospital, Beijing 100853, China
}

Received December 16, 2015; accepted January 19, 2016; published online March 22, 2016

\begin{abstract}
$\mathrm{T}$ cell mediated adoptive immune response has been characterized as the key to anti-tumor immunity. Scientists around the world including in China, have been trying to harness the power of $\mathrm{T}$ cells against tumors for decades. Recently, the biosynthetic chimeric antigen receptor engineered T cell (CAR-T) strategy was developed and exhibited encouraging clinical efficacy, especially in hematological malignancies. Chimeric antigen receptor research reports began in 2009 in China according to our PubMed search results. Clinical trials have been ongoing in China since 2013 according to the trial registrations on clinicaltrials.gov.. After years of assiduous efforts, research and clinical scientists in China have made their own achievements in the CAR-T therapy field. In this review, we aim to highlight CAR-T research and clinical trials in China, to provide an informative reference for colleagues in the field.
\end{abstract}

chimeric antigen receptor, tumor associated antigen, adoptive cell therapy, gene modification, combination strategy

Citation: Luo, C., Wei, J., and Han, W. (2016). Spotlight on chimeric antigen receptor engineered T cell research and clinical trials in China. Sci China Life Sci 59, 349-359. doi: 10.1007/s11427-016-5034-5

\section{INTRODUCTION}

In recent years, chimeric antigen receptor engineered $\mathrm{T}$ cell (CAR-T) therapy emerged as a leading role in the cancer immunotherapy arena (Yang, 2015). The excitement surrounding CAR-T therapy is kindled by thrilling objective results from clinical trials, owing to years of diligent collaborative study from laboratory and clinical scientists. CAR-T was originally proposed by Zelig Eshhar and colleagues working at the Weissman Institute in Israel 27 years ago (Gross et al., 1989). CAR-T combines the recognition advantage of the $\mathrm{scFv}$ (single chain fragment variable) from monoclonal antibodies and the tumor lysis ability of individual $\mathrm{T}$ cells, which enables engineered $\mathrm{T}$ cells to target and kill tumor cells. This MHC (major histocompatibility complex)-independent strategy makes MHC down-

$\dagger$ Contributed equally to this work

*Corresponding author (hanwdrsw69@yahoo.com) regulated tumor cells no longer "invisible" to T cells, and enables the direct triggering of effector functions by CAR molecules (Chmielewski et al., 2013; Oren et al., 2014). Research and clinical trials focusing on CAR-T therapy are in progress worldwide, including in China. According to registrations on clinicaltrials.gov., there are 94 CAR-T cell therapy studies worldwide. China has the second most on-going clinical trials (26 studies) at present. Academic institutions, hospitals, and enterprises in China have launched multiple CAR-T associated studies, with promising outcomes being reported in the past few years. Although in its infancy, CAR-T therapy in China is thriving on challenges and opportunities. In this review, we have summarized the past CAR-T research and clinical trials, and looked into the future of CAR-T therapy in China.

\section{CAR CONSTRUCTS}

CAR constructs are mainly composed of four elements, 
including antigen-recognizing $\mathrm{scFv}$, the spacer and trans-membrane domain, the co-stimulatory domain and the signaling domain (Sadelain et al., 2013).

The most used scFvs in China are derived from well described antibodies, such as anti-CD19 scFv from FMC63 (Dai et al., 2015) and anti-CD20 scFv from HB-9645 (Wang et al., 2014) etc. (Table 1). The use of these scFv fragments to target the well recognized tumor associate antigens partially assure the specificity and safety, which is preferable for clinical trials. Due to the limited number of antigens for tumor cell targeting, some original scFv fragments targeting potential tumor associate antigens have also been developed in China, such as anti-LMP1 (Epstein-Barr virus (EBV) latent membrane protein 1) $\mathrm{scFv}$ for EBV-positive cancer cells (Tang et al., 2014) and antiCMA1 scFv for chronic myeloid leukemia cells (Wang et al., 2012) (Table 1). Most of the scFv sequences are derived from mouse monoclonal antibodies. To avoid potential immunogenicity, humanized antibodies and human antibodies are being developed (Wang et al., 2012). The strategy of using $\mathrm{scFv}$ sequences from the patients' auto-antibodies is proposed to circumvent immunogenicity (Weibo and Zhaoming, 2012). To improve the scFv fragments, scientists abroad screened the affinity of scFvs to control the "on target-off tumor" effect. With respect to the same antigen, low affinity scFvs binding tumor cells rather than healthy tissue are preferred (Cruz, 2014; Zhao et al., 2015). However, given the present technology and the limited human tissue samples, clinical trials are essential for the confirmation of the safety of a given $\mathrm{scFv}$ targeting a given antigen.

The usage of the spacer and trans-membrane domains of CARs are quite empirical; the former mostly depend on the targeting epitope of the specific $\mathrm{scFv}$, while the structural and biochemical impact of the latter remains largely unknown. The spacers used in China are mainly $\mathrm{CH}_{2} \mathrm{CH}_{3}$, Fc hinge, and CD8 $\alpha$ hinge (Deng et al., 2015; Guo et al., 2015; Wang et al., 2013) (Table 1). Recently, it has been reported that $\mathrm{CH}_{2} \mathrm{CH}_{3}$ spacer could bind soluble Fc $\gamma$-receptors and cause off-target cell lysis (Almåsbak et al., 2015), and that the mutation or deletion of the $\mathrm{CH}_{2}$ region could obviate this problem. Previous studies showed that the distance of the target epitope from the cell membrane is an important parameter for the design of a spacer. For epitopes proximal to membrane such as CD22, a longer spacer is better; while for other epitopes such as receptor tyrosine kinase-like orphan receptor 1 (ROR1), shorter spacers are preferred (Hudecek et al., 2013; Turtle, 2013). These studies indicate that, to promote the efficiency of CARs, the spacer domain needs to be tailored for each of the different target molecules. The trans-membrane domains used in China are mainly derived from CD28 and CD8 $\alpha$ (Wang et al., 2014; Zhou et al., 2013). Although comparative results are not yet available, it is presumable that the trans-membrane domains in favor of CAR-based immune synapse formation might be more advantageous.
The co-stimulatory domains used in China are mainly CD28, CD137 and inducible costimulate (ICOS) (Gao et al., 2014; Guo et al., 2015; Zheng et al., 2010) (Table 1). CD28 and ICOS are B7 family members, while CD137 is a member of the tumor necrosis factor receptor (TNFR) family. CD28 co-stimulation is essential for naive $\mathrm{T}$ cells, and ICOS and CD137 are expressed following the induction of CD28 signaling (Curran et al., 2012). CD28 is superior for IL-2 production, and clonal expansion of CAR-T cells. ICOS can help $\mathrm{T}$ cells polarize into TH17/TH1 cells and enhance tumor cell lysis capacity (Finney et al., 2003). CD137 specifically reprogram T cells for multifunctional cytokine secretion and enhanced persistence (Carpenito et al., 2009; Song et al., 2011). CD137 also ameliorates T cell exhaustion induced by the spontaneous signaling of CARs (Long et al., 2015; van der Stegen et al., 2015). Other potential molecules such as OX40 and CD27 are also being used as co-stimulatory domains. OX40 can repress IL-10 secretion and counteract the self-repression of activated $\mathrm{T}$ cells (Hombach et al., 2012). CD27 is able to enhance effector function and proliferation, and mediate greater persistence as compared with CD28 (Song et al., 2012). It is generally agreed that second-generation CARs are more effective than those of the first-generation, but there is no agreement on which co-stimulatory molecule is the best or whether third-generation CARs are superior (Turtle, 2014). This is probably due to the use of different scFvs, different tumor models, different expression systems and different CAR expression levels in each laboratory. For each CAR construct, comparisons of the co-stimulatory molecules in vitro and in vivo are still needed to define the most suitable co-stimulatory domain. The signaling domains used in China are all $\mathrm{CD} 3 \zeta$. $\mathrm{CD} 3 \zeta$ is mainly used as the signaling domain worldwide, while FceRI is less used (Srivastava and Riddell, 2015). Moreover, it is also reported that CD3- $\zeta$ conducts superior signaling efficacy of CARs as compared to FceRI $\gamma$ (Haynes et al., 2001).

In general, the CAR constructs in China are mainly second-generation CARs that synchronize with their global counterparts. In addition to the three generations of CARs, the fourth-generation CARs or "TRUCKs" have been developed abroad (Chmielewski and Abken, 2015). These new CARs endow $\mathrm{T}$ cells with additional cytokine production such as IL-12 (Chmielewski et al., 2011) or IL-15 (Hoyos et al., 2010). Also, other modifications are also introduced into CAR-T cells, such as CD137 co-stimulatory ligand expression (Zhao et al., 2015), bi-specific antigen recognition targeting prostate specific membrane antigen (PSMA) and prostate stem cell antigen (PSCA) (Kloss et al., 2013), and extracelluar matrix degradation with heparanase (Caruana et al., 2015) etc.. Recently, an on-switch CAR paradigm was also developed, which allowed the activation of CAR-T cells to be controlled by small molecules ( $\mathrm{Wu}$ et al., 2015). Although the next generation strategies help to improve the function of CAR-T cells, they also increase the 
Table 1 Published Results on CAR-T therapy in China ${ }^{\text {a) }}$

\begin{tabular}{|c|c|c|c|c|c|c|c|}
\hline Antigen & Tumor target & Sponsor & Receptor & Culture & $\begin{array}{l}\text { Gene } \\
\text { transfer }\end{array}$ & Model & Date \\
\hline CD123 & $\begin{array}{l}\text { Acute myeloid } \\
\text { leukemia }\end{array}$ & $\begin{array}{l}\text { Anhui Provincial Hospital; Baylor } \\
\text { College of Medicine }\end{array}$ & scFv-IgG4Fc-CD28-CD3zeta & $\mathrm{CD} 3+\mathrm{CD} 28+\mathrm{IL}-2$ & $\begin{array}{l}\text { Retrovi- } \\
\text { ruse }\end{array}$ & Vitro & 2015 \\
\hline CD138 & Multiple myeloma & Chinese PLA General Hospital & $\begin{array}{l}\text { scfv-CD8a hinge and } \\
\text { TM-CD137-CD3zeta }\end{array}$ & CD3+IFN-r+IL-2 & Lentivirus & Human & 2014 \\
\hline CD19 & $\begin{array}{l}\text { B-cell lineage } \\
\text { acute lymphocytic } \\
\text { leukemia }\end{array}$ & Chinese PLA General Hospital & $\begin{array}{l}\text { scfv-CD8a hinge and } \\
\text { TM-CD137-CD3zeta }\end{array}$ & CD3+IFN-r+IL-2 & Lentivirus & Human & 2015 \\
\hline $\mathrm{CD} 20$ & $\begin{array}{l}\text { Chemotherapy } \\
\text { refractory ad- } \\
\text { vanced diffuse } \\
\text { large B cell lym- } \\
\text { phoma }\end{array}$ & Chinese PLA General Hospital & $\begin{array}{l}\text { scfv-CD8a hinge and } \\
\text { TM-CD137-CD3zeta }\end{array}$ & CD3+IFN-r+IL-2 & Lentivirus & Human & 2014 \\
\hline CD20 & B-cell lymohoma & $\begin{array}{l}\text { The First Affiliated Hospital of } \\
\text { Wenzhou Medical College }\end{array}$ & 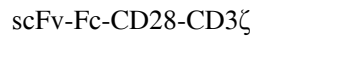 & PHA-L+CD3+IL-2 & $\begin{array}{l}\text { Electro- } \\
\text { poration }\end{array}$ & Vitro & 2010 \\
\hline CD33 & $\begin{array}{l}\text { Acute myeloid } \\
\text { leukemia }\end{array}$ & Chinese PLA General Hospital & $\begin{array}{l}\text { scfv-CD8a hinge and } \\
\text { TM-CD137-CD3zeta }\end{array}$ & CD3+IFN-r+IL-2 & Lentivirus & Human & 2015 \\
\hline EGFR & NSCLC & $\begin{array}{l}\text { West China Hospital, Sichuan } \\
\text { University }\end{array}$ & $\begin{array}{l}\text { scfv-IgG2 } \\
\text { Fc-CD28TM-CD28-CD3zeta }\end{array}$ & $\mathrm{CD} 3+\mathrm{CD} 28+\mathrm{IL}-2$ & $\begin{array}{l}\text { Electro- } \\
\text { poration }\end{array}$ & $\begin{array}{l}\text { NOD/SCID } \\
\text { CB-17 mice }\end{array}$ & 2013 \\
\hline EGFR & $\begin{array}{l}\text { EGFR positive } \\
\text { malignancies }\end{array}$ & $\begin{array}{l}\text { Huaihe Hospital of Henan Univer- } \\
\text { sity }\end{array}$ & $\begin{array}{l}\text { scfv-CD8a hinge and } \\
\text { TM-CD28-CD3zeta }\end{array}$ & $\begin{array}{l}\text { CD3+IFN-r+IL-1be } \\
\text { ta+IL-2 }\end{array}$ & Lentivirus & $\begin{array}{l}\text { BALB/c } \\
\text { nude }\end{array}$ & 2015 \\
\hline EGFRvIII & Glioma & Peking University & $\begin{array}{l}\text { avidin-CD8-CD28-TNFRSF9- } \\
\text { CD3zeta }\end{array}$ & $\mathrm{CD} 3+\mathrm{CD} 28+\mathrm{IL}-2$ & Lentivirus & $\begin{array}{l}\mathrm{BALB} / \mathrm{c} \\
\text { nude mice }\end{array}$ & 2015 \\
\hline EGFRvIII & Glioma & $\begin{array}{l}\text { Zhengzhou University People's } \\
\text { Hospital }\end{array}$ & 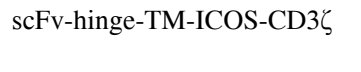 & $\mathrm{CD} 3+\mathrm{CD} 28+\mathrm{IL}-2$ & Lentivirus & $\begin{array}{l}\mathrm{BALB} / \mathrm{c} \\
\text { nude mice }\end{array}$ & 2013 \\
\hline EpCAM & $\begin{array}{l}\text { Prostate } \\
\text { cancer }\end{array}$ & $\begin{array}{l}\text { Peking Union Medical College and } \\
\text { Chinese Academy of Medical } \\
\text { Sciences }\end{array}$ & scfv-CD28-CD3zeta & $\mathrm{CD} 3+\mathrm{CD} 28+\mathrm{IL}-2$ & $\begin{array}{l}\text { Retrovi- } \\
\text { ruse }\end{array}$ & $\begin{array}{l}\text { NOD/SCID } \\
\text { mice }\end{array}$ & 2015 \\
\hline ErbB2 & $\begin{array}{l}\text { Breast/ovarian } \\
\text { cancer }\end{array}$ & Wenzhou Medical College & $\mathrm{scFv}-\mathrm{Fc}-\mathrm{CD} 28-\mathrm{CD} 3 \mathrm{z}$ & PHA-L+CD3+IL-2 & $\begin{array}{l}\text { Electro- } \\
\text { poration }\end{array}$ & $\begin{array}{l}\text { Balb/c nude } \\
\text { mice }\end{array}$ & 2014 \\
\hline ErbB2 & Breast cancer & Wenzhou Medical College & scFv-Fc-CD28-CD3 & PHA-L+CD3+IL-2 & $\begin{array}{l}\text { Electro- } \\
\text { poration }\end{array}$ & Vitro & 2012 \\
\hline ErbB2 & Breast cancer & $\begin{array}{l}\text { The Second Military Medical } \\
\text { University }\end{array}$ & $\begin{array}{l}\text { scfv-cMyc } \\
\text { tag-CD28-CD3zeta }\end{array}$ & $\mathrm{CD} 3+\mathrm{CD} 28+\mathrm{IL}-2$ & Retrovirus & $\begin{array}{l}\mathrm{BALB} / \mathrm{c} \\
\text { mice }\end{array}$ & 2009 \\
\hline $\begin{array}{l}\text { NKG2D } \\
\text { ligands }\end{array}$ & $\begin{array}{l}\text { Gastric cancer } \\
\text { peritoneal metas- } \\
\text { tasis }\end{array}$ & $\begin{array}{l}\text { Shandong Cancer Hospital and } \\
\text { Institute }\end{array}$ & NKG2D-CD28-CD3zeta & $\mathrm{CD} 3+\mathrm{CD} 28$ & Lentivirus & Vitro & 2015 \\
\hline GPC3 & $\begin{array}{l}\text { Hepatocellular } \\
\text { carcinoma }\end{array}$ & $\begin{array}{l}\text { Renji Hospital, Shanghai Jiaotong } \\
\text { University }\end{array}$ & $\begin{array}{l}\text { eGFP-scfv-CD8a } \\
\text { hinge-CD28TM-CD28-CD13 } \\
\text { 7-CD3zeta }\end{array}$ & $\mathrm{CD} 3+\mathrm{CD} 28+\mathrm{IL}-2$ & Lentivirus & $\begin{array}{l}\text { NOD/SCID } \\
\text { mice }\end{array}$ & 2014 \\
\hline LMP1 & $\begin{array}{l}\text { Nasopharyngeal } \\
\text { carcinoma }\end{array}$ & Nanjing Medical University & $\begin{array}{l}\text { scfv-IgG1CH2CH3-CD28-CD } \\
\text { 3zeta }\end{array}$ & CD3+CD28+IL-2 & Lentivirus & $\begin{array}{l}\mathrm{BALB} / \mathrm{c} \\
\text { nude mice }\end{array}$ & 2014 \\
\hline VEGFR-1 & $\begin{array}{l}\text { Breast/NSCL/cerv } \\
\text { ix cancer }\end{array}$ & $\begin{array}{l}\text { West China Hospital, Sichuan } \\
\text { University }\end{array}$ & $\begin{array}{l}\text { scfv-hinge-IgG1 } \\
\text { Fc-CD4TM-CD3zeta }\end{array}$ & CD3+IL-2 & $\begin{array}{l}\text { Electro- } \\
\text { poration }\end{array}$ & $\begin{array}{l}\text { NOD-SCID } \\
\text { BALB/c } \\
\text { mice }\end{array}$ & 2013 \\
\hline
\end{tabular}

a) The published results are collected from PubMed search results with combinations including "chimeric antigen receptor" and "CAR-T cells", and the results are collected before 15th January 2016. Due to the limited collection approach, the results might not be comprehensive, please understand if there are any omissions.

difficulty of gene modification, and the safety and efficacy of these newly developed constructs have yet to be established in human studies (Chmielewski and Abken, 2015). In China, the next-generation CARs are also being developed at present, and hopefully, they will help improve the safety and efficacy of CARs, thus taking Chinese CARs to the next level.

\section{CAR-T CELL CULTURE AND ENGINEERING}

In China, $\mathrm{T}$ cells used for CAR modification are acquired from peripheral blood mononuclear cell (PBMC) culture. To activate $\mathrm{T}$ cells, combination such as OKT3+CD28, OKT3+ interferon gamma $(\mathrm{IFN}-\gamma)$ or phytohemagglutinin
(PHA)-L+IL-2 are used for days of stimulation, after which, the cells are maintained with IL-2 (Table 1). The whole culture process lasts about 10-14 d (Gao et al., 2014; Wang et al., 2014, 2015). The stimulation process aims to make $\mathrm{T}$ cells susceptible to viral transduction, especially retrovirus, and to achieve a large number of $\mathrm{T}$ cells. $\mathrm{T}$ cells infused back to patients are expanded about 100-1,000 fold in vitro, which tend to induce $\mathrm{T}$ cell terminal differentiation. Preclinical studies abroad showed that the adoptive transfer of $\mathrm{T}$ cells with the less differentiated naïve and central memory phenotype have greater persistence and antitumor effects than the transfer of terminally differentiated effector cells (Gattinoni et al., 2005, 2011; Hinrichs et al., 2011). To achieve the less differentiated cells, one approach is to iso- 
late the $\mathrm{T}_{\mathrm{N}}$ (Naïve $\mathrm{T}$ ) or $\mathrm{T}_{\mathrm{CM}}$ (central memory $\mathrm{T}$ ) cells (Wang et al., 2012), while the other approach is to optimize the culture condition to accommodate the less differentiated cells. Recently, $\gamma$-chain cytokines including IL-7, IL-15, and IL-21 have been shown to better preserve the naive and central memory phenotype of $\mathrm{T}$ cells compared to IL-2 (Perna et al., 2014; Singh et al., 2011; Xu et al., 2014). The usage of these cytokines could be in favor of the T cell culture in China. Additionally, because the less differentiated $\mathrm{T}$ cells have greater proliferative potential and tumoricidal capacity in vivo, the culture time and transfer dose of $\mathrm{T}$ cells might be reduced. This will simplify the practicalities of CAR-T cell production and hopefully improve the whole delivery system.

The gene modification methods of CAR-T cells in China are mainly lentivirus (Wang et al., 2015), retrovirus transduction (Deng et al., 2015) and plasmid electro-transfection (Wang et al., 2013) (Table 1). Virus transduction is favorable for inserting the gene of interest into the target cell genome and precipitating continuous expression. While plasmid transfection enables the transient expression of genes, stable expression can be achieved through additive antibiotic screening. The virus system is more advantageous for creating stable CAR expressing $\mathrm{T}$ cell and prolonging CAR expressing $\mathrm{T}$ cells in vivo. Although there is a remote possibility that retrovirus or lentivirus conducted gene insertion could induce oncogenic-associated mutations, evidences from clinical studies till now indicate that this approach is generally safe (Barrett et al., 2014; Gill and June, 2015). Moreover, transposon systems such as sleeping beauty (Deniger et al., 2015; Singh et al., 2015) and piggybac (Nakazawa et al., 2011; Ramanayake et al., 2015) have been explored for CAR modification and used in hematological malignancy therapies abroad, the clinical safety and efficacy of which are under evaluation. The temporary expression of CAR conducted by recently developed mRNA transfection is also accepted because it will not cause insertional mutagenesis. Also, the limited expression time is preferable for CARs targeting antigens with potential risk (Kenderian et al., 2015; Krug et al., 2014). Theoretically, lentiviruses and transposons can transfect undivided cells, and thus avoid stimulation induced $\mathrm{T}$ cell differentiation; however, stimulation with mitogenic agents is still needed to change the resistant state of primary $\mathrm{T}$ cells (Cheadle et al., 2014; Morgan and Kakarla, 2014). Besides, transcription activator-like effector nuclease (TALEN) system is used to knock out TCR and CD52, in order to achieve "off the shelf" CAR-T cells (Couzin-Frankel, 2015; Poirot et al., 2015). Other gene editing tools such as CRISPR/Cas9 are also being used to develop more favorable CAR-T phenotype. An approach that is able to efficiently transfect $\mathrm{T}$ cells without causing $\mathrm{T}$ cell differentiation is ideal. The present gene delivery systems may be satisfactory for mouse studies and clinical trials, but they are still expensive and difficult for steady large-scale production. In general, an optimal gene delivery system is crucial for the CAR industry and clinical efficacy, the improvement of which will promote the development of the industry as a whole. Considering that CAR-T therapy is a personalized treatment strategy and that the engineering and transportation processes are crucial, it is necessary to build multiple regional clinical trial stations. Cooperation between multiple local research institutions and hospitals would help in the building of this CAR-T clinical trial network.

\section{CAR-T CELLS TARGETING HEMATOLOGICAL MALIGNANCIES}

CAR-T cells are used in treating hematological malignancies including acute lymphocytic leukemia, chronic lymphocytic leukemia, lymphoma and multiple myeloma. The target antigens include CD19 (Dai et al., 2015), CD20 (Wang et al., 2014), CD30, CD33 (Wang et al., 2015) and CD138 (Guo et al., 2015) (Table 2). CD19 is the most popular target in China, where clinical trials are being conducted in institutions including the Chinese PLA General Hospital, Affiliated Hospital to Academy of Military Medical Sciences and The Second Hospital of Anhui Medical University etc.. According to PubMed search results, the published clinical data in China are mainly from the Chinese PLA General Hospital. To date, three clinical studies have been reported. In a pilot clinical trial, autologous or donor-derived $\mathrm{T}$ cells modified to express CAR19 were used to treat patients with relapsed or chemotherapy-refractory B-cell lineage acute lymphocytic leukemia (B-ALL). Nine patients were enrolled, six of whom had extramedullary involvement. Five patients had objective hematopoietic system and extramedullary tissue response for 2-9 months. Cytokine release syndrome (CRS) was observed in most cases. In two patients who received donor-derived cells, grade 2-3 graft-versus-host disease (GVHD) was observed (Dai et al., 2015). Moreover, patients with chemotherapy refractory advanced diffuse large B cell lymphomas (DLBCL) were treated with CAR20 T cells. Two patients with no bulky tumors were enrolled, and one achieved a durable complete remission for 14 months while the other achieved a 6-month regression. Five patients with bulky tumor burdens were also treated, and three of them achieved tumor regressions lasting 3-6 months. The associated toxicities mainly included cytokine release syndrome, tumor lysis syndrome, alimentary tract hemorrhage and intrapulmonary inflammation surrounding extranodal lesions (Wang et al., 2014). Also, one patient with acute myeloid leukemia (AML) was treated with CAR33 T cells. A marked decrease of blasts in the bone marrow was observed two weeks after therapy, and there was a gradual increase until disease progression occurred nine weeks after therapy. Cytokine release syndrome was also observed in the patient (Wang et al., 2015). In these studies, it was observed that CAR-T cells reached their peak 2-3 weeks after cell infusion, and this 
Table 2 Clinical trials in China infusing CAR-T cells ${ }^{\text {a) }}$

\begin{tabular}{|c|c|c|c|c|c|c|}
\hline Antigen & Tumor target & Sponsor & Phase & $\begin{array}{l}\text { Number } \\
\text { enrolled }\end{array}$ & NCT Number & $\begin{array}{l}\text { Study } \\
\text { start }\end{array}$ \\
\hline CD133 & $\begin{array}{l}\text { Liver cancer; Pancreatic cancer; Brain } \\
\text { tumor; Breast cancer; Ovarian tumor; } \\
\text { Colorectal cancer; Acute myeloid and } \\
\text { lymphoid leukemias }\end{array}$ & Chinese PLA General Hospital & Phase 1 & 20 & NCT02541370 & 2015 \\
\hline CD138 & $\begin{array}{l}\text { Relapsed and/or chemotherapy resistant } \\
\text { multiple myeloma }\end{array}$ & Chinese PLA General Hospital & Phase 1 / Phase 2 & 10 & NCT01886976 & 2013 \\
\hline CD19 & Acute lymphoblastic leukemia & $\begin{array}{l}\text { Affiliated Hospital to Academy of } \\
\text { Military Medical Sciences; Peking } \\
\text { University }\end{array}$ & Phase 1 & 5 & NCT02186860 & 2015 \\
\hline CD19 & $\begin{array}{l}\text { Non-hodgkin lymphoma; Mantle cell } \\
\text { lymphoma }\end{array}$ & Chinese PLA General Hospital & Phase 1 / Phase 2 & 2 & NCT02081937 & 2014 \\
\hline CD19 & $\begin{array}{l}\text { Relapsed and/or chemotherapy refractory } \\
\text { B-cell malignancy }\end{array}$ & Chinese PLA General Hospital & Phase 1 & 12 & NCT01864889 & 2013 \\
\hline CD19 & B-cell lymphomas & $\begin{array}{l}\text { Peking University; University of } \\
\text { Florida }\end{array}$ & Phase 1 / Phase 2 & 20 & NCT02247609 & 2014 \\
\hline CD19 & $\begin{array}{l}\text { Relapsed/refractory leukemia and lym- } \\
\text { phoma }\end{array}$ & $\begin{array}{l}\text { Shanghai Tongji Hospital, Tongji } \\
\text { University School of Medicine }\end{array}$ & Phase 1 / Phase 2 & 40 & NCT02537977 & 2015 \\
\hline CD19 & $\begin{array}{l}\text { Chronic lymphocytic leukemia; Acute } \\
\text { lymphocytic leukemia; Lymphoma }\end{array}$ & $\begin{array}{l}\text { Shenzhen Second People's Hospital; } \\
\text { Shenzhen institute for innovation and } \\
\text { translational medicine }\end{array}$ & Phase 1 & 36 & NCT02456350 & 2015 \\
\hline CD19 & Leukemia; Lymphoma & Southwest Hospital & Phase 1 & 45 & NCT02349698 & 2014 \\
\hline CD19 & Recurrent or refractory B-cell tumor & Second Military Medical University & Phase 1 / Phase 2 & 20 & NCT02644655 & 2015 \\
\hline CD19 & Leukemia; Lymphoma & $\begin{array}{l}\text { Beijing Doing Biomedical Co., Ltd.; } \\
\text { First Hospital of Jilin University }\end{array}$ & Phase 1 & 100 & NCT02546739 & 2016 \\
\hline CD19 & $\begin{array}{l}\text { Recurrent or stage III/IV diffuse large cell } \\
\text { lymphoma; Follicular lymphoma; Mantle } \\
\text { cell lymphoma }\end{array}$ & Xinqiao Hospital of Chongqing & Phase 1 / Phase 2 & 20 & NCT02652910 & 2015 \\
\hline CD30 & $\begin{array}{l}\text { Hodgkin's lymphoma; Non-Hodgkin's } \\
\text { lymphoma }\end{array}$ & Chinese PLA General Hospital & Phase 1 / Phase 2 & 30 & NCT02259556 & 2014 \\
\hline CD30 & Lymphomas & $\begin{array}{l}\text { Peking University; University of } \\
\text { Florida }\end{array}$ & Phase 1 / Phase 2 & 20 & NCT02274584 & 2014 \\
\hline CD33 & $\begin{array}{l}\text { Relapsed and/or chemotherapy refractory } \\
\text { adult myeloid leukemia }\end{array}$ & Chinese PLA General Hospital & Phase 1 / Phase 2 & 10 & NCT01864902 & 2013 \\
\hline CEA & $\begin{array}{l}\text { Lung cancer; Colorectal cancer; Gastric } \\
\text { cancer; Breast cancer; Pancreatic cancer }\end{array}$ & Southwest Hospital & Phase 1 & 75 & NCT02349724 & 2014 \\
\hline EGFR & Advanced EGFR-positive solid tumors & Chinese PLA General Hospital & Phase 1 / Phase 2 & 10 & NCT01869166 & 2013 \\
\hline EGFR & Advanced glioma & RenJi Hospital & Phase 1 & 10 & NCT02331693 & 2014 \\
\hline EphA2 & EphA2 positive malignant glioma & Fuda Cancer Hospital & Phase 1 / Phase 2 & 60 & NCT02575261 & 2015 \\
\hline GPC3 & Hepatocellular carcinoma & RenJi Hospital & Phase 1 & 10 & NCT02395250 & 2015 \\
\hline HER-2 & $\begin{array}{l}\text { Chemotherapy and/or HER-2 antibody } \\
\text { inhibitor therapy refractory advanced } \\
\text { HER-2 positive solid tumors }\end{array}$ & Chinese PLA General Hospital & Phase 1 / Phase 2 & 10 & NCT01935843 & 2013 \\
\hline HER-2 & Breast cancer & Fuda Cancer Hospital & Phase 1 / Phase 2 & 60 & NCT02547961 & 2015 \\
\hline $\begin{array}{l}\text { Meso- } \\
\text { thelin }\end{array}$ & $\begin{array}{l}\text { Malignant mesothelioma; Pancreatic can- } \\
\text { cer; Ovarian tumor; Triple negative breast } \\
\text { cancer; Endometrial cancer; Other meso- } \\
\text { thelin positive tumors }\end{array}$ & Chinese PLA General Hospital & Phase 1 & 20 & NCT02580747 & 2015 \\
\hline MUC1 & $\begin{array}{l}\text { Malignant glioma of brain; Colorectal } \\
\text { carcinoma; Gastric carcinoma }\end{array}$ & $\begin{array}{l}\text { PersonGen Biomedicine (Suzhou) Co., } \\
\text { Ltd.; Anhui General Hospital of } \\
\text { Armed Police Forces }\end{array}$ & Phase 1 / Phase 2 & 20 & NCT02617134 & 2015 \\
\hline
\end{tabular}

a) The clinical trials are collected from clinicaltrial.gov., search results with combinations including "chimeric antigen receptor" and "CAR-T cells", and the results are collected before 15th January 2016. Due to the limited collection approach, the results might not be comprehensive, please understand if there are any ommissions.

was maintained for a couple of months. Broadly speaking, these clinical results are highly inspiring with multiple reports of objective clinical responses in patients with advanced, chemo-refractory hematological malignancies treated with CAR modified T cells.

Some clinical issues are also addressed in these studies. Preconditioning therapy has been shown to enhance the efficacy of CAR-T therapies. On one hand, the lympho- depletion treatments could induce the clearance of Tregs and help the expansion of infused $\mathrm{T}$ cells in a lymphocyte homeostatic fashion (Rosenberg and Restifo, 2015). On the other hand, the de-bulking treatments could reduce the tumor burden and disrupt the tumor structure, thus enhancing the trafficking of $\mathrm{T}$ cells and mitigating tumor lysis syndromes (Lee et al., 2014). Toxicities including cytokine release syndrome, tumor lysis syndrome, neural toxicity and 
inflammation accompany with clinical efficiencies. To ensure the safety of CAR-T cell transfusion, the cell doses are used in an escalating manner. Etanercept (anti-TNFa), tocilizumab (anti-IL-6R) or corticosteroids are used for controlling cytokine release syndromes (Wang et al., 2014). Organ distribution is decisive for CAR-T cells to interact with tumor cells. It is reported that CAR copies can be detected in the bone marrow, cerebrospinal fluid and nodules, but cannot be detected in adipose and extramedullary tissues. The distribution patterns of CAR-T cells provide an explanation for the different clinical responses after cell infusions. Furthermore, donor-derived $\mathrm{T}$ cells can cause GVHD (graft-versus-host disease) for some patients, indicating that CAR-T cells should be used with caution for patients who have received allogeneic hematopoietic stem cell transplantation (allo-HSCT) (Dai et al., 2015). For these patients, EBV specific T cells (Pule et al., 2008; Terakura et al., 2012) or TCR $\alpha \beta$-knocked out CAR-T cells (Poirot et al., 2015 ) are possible solutions. EBV specific $T$ cells or TCR $\alpha \beta$-deficient $\mathrm{T}$ cells are not able to recognize host antigens, and thus, the attack of host tissues can be avoided (Cruz et al., 2013; Poirot et al., 2015; Valton et al., 2015).

Generally speaking, hematological malignancies are most responsive to CAR-T therapy so far. Inspiring results of CAR-T-19 therapy from the Memorial Sloan Kettering Cancer Center (Davila et al., 2014), the National Cancer Institute (Lee et al., 2015) and the University of Pennsylvania (Maude et al., 2014) have been reported. In accordance with studies in China, they have all reported the feasibility and anti-tumor efficacy of CAR-T cells against hematological tumors. According to the data reported, complete remission (CR) rates in China are not as high as in the US (Maude et al., 2015). The patients' background largely accounts for this difference. In China, the participants recruited in clinical trials are often more heavily treated and in their later stages as compared to the participants in the US. Clinicians in China would largely improve this situation if they would encourage patients relapsed or refractory from standard treatments to participate in reliable clinical trials.

There are some attributes of hematological malignancies that make them suitable targets for CAR-T therapy. In hematological malignancies, the tumor cells are in the circulation system, which makes them easier for $\mathrm{T}$ cells to intercept and more accessible for evaluation (Porter et al., 2015). Tumor-specific antigen expression is relatively limited. For example, CD19 is restrictedly expressed by B cells, which is favorable for avoiding on target-off tumor toxicity. Since the target cells are in the circulation system, the infused $\mathrm{T}$ cells can be directly activated by the antigens and maintained in the system for immune surveillance. Hematological tumor cells always express co-stimulatory molecules, whereas solid tumor cells usually lack such molecules (Maude et al., 2015; Sadelain, 2015; Turtle, 2014). With these advantageous features for CAR-T therapy, the clinical outcomes of hematological malignancies are quite encouraging. In contrast, due to their lack of natural favorable characteristics, non-hematological malignancies remain as challenging targets for CAR-T therapy.

\section{CAR-T CELLS TARGETING NON-HEMATOLOGICAL MALIGNANCIES AND COMBINATORIAL STRATEGIES}

In contrast to the success observed in the treatment of hematological malignancies, there is a lack of encouraging clinical data about CAR-T therapy for solid tumors. In China, according to published results, $\mathrm{T}$ cells are modified with CARs targeting EpCAM (epithelial cell adhesion molecule) for prostate cancer (Dai et al, 2015), EGFRvIII (epidermal growth factor receptor variant III) for glioma (Liu et al., 2015; Shen et al., 2013), LMP1 for nasopharyngeal cancer (Tang et al., 2014), GPC-3 (glypican-3) for hepatocellular carcinoma (Gao et al., 2014), and VEGFR-1 (vascular endothelial growth factor receptor 1) (Gao et al., 2015) and EGFR (Zhou et al., 2013) for multiple tumors (Table 1). These preclinical studies have shown potential and have paved the way for the evaluation of CARs in clinical settings. According to the clinical trial registrations, CARs targeting EGFR, Her-2 (human epidermal growth factor receptor-2), EGFRvIII and GPC-3 for multiple solid tumors are under investigation (Table 2). To improve the efficacy of CARs in targeting non-hematological malignancies, there are some issues that need to be addressed.

Tumor antigens used as CAR targets mainly include mutated antigens, lineage antigens and over-expressed antigens. In hematological malignancies, especially B cell malignancies, the most successful target antigen CD19 is lineage restricted. The targeting of such a lineage limited antigen is relatively safe, and its eradication can lead to consequences that are remediable (Maude et al., 2015; Sadelain, 2015). For solid tumors, mutated antigens are attractive targets. EGFRvIII is the most common variant of EGFR observed in human tumors, and particularly in glioblastoma. CARs targeting EGFRvIII have been developed for glioblastoma, after the demonstration of safety and efficacy in mouse models, phase I clinical trial is underway (Johnson et al., 2015; Morgan et al., 2012). Mutated antigens and lineage antigens are favorable but rare, and most of the available antigens are over-expressed antigens such as EGFR, Her-2 and GPC-3. These antigens expressed in tumor cells are also expressed in normal cells at lower level. This makes the on target-off tumor toxicity a critical issue (Hinrichs and Restifo, 2013; Kakarla and Gottschalk, 2014; Song et al., 2015). ScFv affinity optimization is helpful for solving this problem (Caruso et al., 2015; Liu et al., 2015). The future development of CARs targeting solid tumor antigens in China may also benefit from $\mathrm{scFv}$ affinity optimization. Moreover, the safety switch iCaspase 9 (Budde et al., 2013) and iCAR 
strategy (Fedorov et al., 2013) also have potential to divert off-target immune responses.

Effective CAR-T therapy requires not only the generation of cancer-specific $\mathrm{T}$ cells, but also that these $\mathrm{T}$ cells can physically contact cancer cells directly. Solid tumors are known to be comprised of abundant extracellular matrix and tumor-associated stroma cells. The structure and microenvironment of solid tumors makes them privileged for $\mathrm{T}$ cell exclusion. Such a circumstance makes $\mathrm{T}$ cell traffic a herculean hurdle for CAR-T therapy in solid tumors (Joyce and Fearon, 2015). To improve the trafficking of adoptive transferred $\mathrm{T}$ cells, some approaches have been developed abroad in recent years. Prasad et al. compared conventional systemic intravenous and regional intra-pleural administration for the treatment of malignant pleural mesothelioma. They found that intra-pleural $\mathrm{T}$ cell administration was superior against pleural disease and even disseminated tumor sites (Adusumilli et al., 2014). For solid tumors residing in elastic cavities, this regional administration approach may be an advantageous option. T cell traffic in the tumor blood vessel requires the interaction between chemokines and chemokine receptors (CCR) (Molon et al., 2011). Edmund et al. found that CAR-T cells with chemokine receptor expression had superior tumor localization and antitumor efficacy as compared with conventional CAR-T cells (Moon et al., 2011). Thus, for the treatment of tumors secreting an abundance of certain types of chemokines, the modification of CAR-T cells to express matched CCRs is beneficial. Once $\mathrm{T}$ cells enter the tumor mass, extracellular matrix (ECM) in stroma-rich solid tumors forms another defense against $\mathrm{T}$ cell attacks. To ensure the continuous contact of $\mathrm{T}$ cells and tumor cells, T cells must be able to degrade ECM (Tan et al., 2015). Ignazio et al. engineered CAR-T cells to constitutively express heparanase, an enzyme that is able to degrade heparan sulfate proteoglycans, which are the primary components of ECM. Heparanase significantly promotes tumor infiltration and the antitumor activities of CAR-T cells (Caruana et al., 2015). This study provided a potential approach that may enhance the efficiency of CAR-T cells, especially in stroma-rich solid tumors. The strategies above may help improve CAR-T cell structure in China, but they also need to be used with caution to prevent potential off-tumor toxicities.

When CAR-T cells enter the tumor mass, they confront with multiple immune suppressive factors, including hypoxia, low $\mathrm{pH}$, the lack of metabolic components, tumor-derived cytokines or metabolites, immune suppressor cells, and inhibitory receptors (Beavis et al., 2015; Gajewski et al., 2013). Though co-stimulatory molecules such as CD28 and CD137 can maintain the survival of CAR-T cells, they do not sufficiently protect CAR-T cells from the inhibition induced by the tumor microenvironment. It is reported that CAR-T cell hypofunction was reversible when the cells were isolated from the tumor. Multiple factors contribute to the hypofunction of $\mathrm{T}$ cells, including intrinsic $\mathrm{T}$ cell inhibitory enzymes and the expression of surface inhibitory receptors (PD-1, LAG3, TIM3, and 2B4) (Beavis et al., 2015; Enblad et al., 2015; Moon et al., 2014). The interception of immune suppressive factors such as indoleamine 2,3-dioxygenase (IDO) and PD-1 is proved to enhance the antitumor activity of CAR-T cells (John et al., 2013; Ninomiya et al., 2015). Inhibition of Akt signaling is also proven to promote the generation of superior tumor-reactive T cells by studies in China and abroad (van der Waart et al., 2014, 2015; Wu et al., 2015). Except for these combinatorial therapies aimed at counteracting immune suppressive effects, other promising combinatorial strategies have also been evaluated. Epigenetic modifiers, capable of up-regulating tumor antigen expression and increasing tumor antigen intensity, are beneficial for the eradication of tumor cells by CAR-T cells (Anurathapan et al., 2014). Whole Cell vaccine is also reported to enhance antitumor responses of CAR-redirected cytotoxic T lymphocytes recently (Caruana et al., 2015). Chemotherapy is already used as pre-conditioning therapy in hematological malignancies. For solid tumors, chemotherapy and other tumor cytotoxic agents are able to change the tumor structure by inducing tumor cell death, affecting tumor stromal cells, and even reducing myeloid-derived suppressor cells (MDSCs) (Mahoney et al., 2015). These changes in the tumor microenvironment induced by tumor cytotoxic agents suggest it as a synergistic companion for CAR-T therapy. Additionally, new combinations of CAR-T therapy and other current approaches including radiotherapies and antibodies targeting tumor cells also require further exploration.

\section{FINAL THOUGHTS}

CAR-T therapy has brought a new hope to cancer patients around the world, including China. However, there are still issues to be solved for CAR-T cell application, including side effects such as on target-off tumor effect, CRS and neural toxicity, optimal cell dosage and infusion frequency, enhancement of specificity and efficacy for solid tumors, and recurrence and treatment post CAR-T therapy. Adoptive immune cell therapy is categorized as one of the third kind medical technologies in China. A notice was released by the National Health and Family Planning Commission of PRC (NHFPC) on June 29th, 2015. This notice declares the cancelation of the approval procedure of the third kind medical technologies clinical application in China, and in its place, a registration system has been adopted. Medical organizations are responsible for the clinical application of the third kind medical technologies themselves. This notice made CAR-T therapy more accessible to general medical organizations; however, due to its potential side effects and toxicities, the clinical application of CAR-T cells should be pursued with caution. Since the understanding of CAR-T therapy is limited so far, large-scale general hospitals with both medical and research orientations are favorable to the 
clinical application and development of CAR-T therapy. Since the process of CAR-T therapy involves both cell processing approaches and gene modification products, it is presumable that the approval of this therapy would require the certification of both in the future. For the future industrialization of CAR-T therapy, the cooperation of enterprises and medical organizations will be helpful. In the US, Juno cooperates with the University of Pennsylvania Medical Center and Kite collaborates with National Cancer Institute. In China, Cellular Biomedicine Group partners with the Chinese PLA General Hospital. It is estimated that CAR-T therapy would cost tens of thousands of RMB for one patient; therefore, large-scale clinical trials of CAR-T therapy would be in need of a large amount of financial support. Wall Street has already provided financial support for CAR-T therapy in the US (Barrett et al., 2015). Although the use of CAR-T therapy is still in the early phases in China, we believe that the Chinese financial market will also lend a hand for CAR-T therapy in the near future. In recent years, basic researches aim to improve CAR-T efficacy, safety, universality and applicability for treating solid tumors have made achievements in other nations worldwide. Institutes or enterprises abroad have grown to be skilled in their particular areas. In China, though we have the second most CAR-T clinical trials for now, we are still in lack of self-dependent innovations so far. It is presumable that if "CARs" made in China want to go further, basic research aim to understand and improve the present CAR is indispensable. To accelerate CAR-T therapy in China, we need to strengthen the independent research and development of CAR-T cells, establish the safe and standard clinical research systems, and actively carry out the relevant knowledge and application training of clinicians. The structure of CAR at present has achieved the recognition and stimulation of $\mathrm{T}$ cells. This has already exhibited surprising anti-tumor effects. We believe that the dis-inhibition of CAR-T cells and other combination strategies have great potential for promoting this therapy forward.

Compliance and ethics The author(s) declare that they have no conflict of interest.

Acknowledgements This work was supported by Science and Technology Planning Project of Beijing City (Z151100003915076 to Weidong Han), and National Natural Science Foundation of China (31270820, 81230061 to Weidong Han, 81502679 to Can Luo).

Adusumilli, P.S., Cherkassky, L., Villena-Vargas, J., Colovos, C., Servais, E., Plotkin, J., Jones, D.R., and Sadelain, M. (2014). Regional delivery of mesothelin-targeted CAR $\mathrm{T}$ cell therapy generates potent and long-lasting CD4-dependent tumor immunity. Sci Transl Med 6, 261 ra151.

Almåsbak, H., Walseng, E., Kristian, A., Myhre, M.R., Suso, E.M., Munthe, L.A., Andersen, J.T., Wang, M.Y., Kvalheim, G., Gaudernack, G., and Kyte, J.A. (2015). Inclusion of an IgG1-Fc spacer abrogates efficacy of CD19 CAR T cells in a xenograft mouse model. Gene Ther
$22,391-403$.

Anurathapan, U., Chan, R.C., Hindi, H.F., Mucharla, R., Bajgain, P., Hayes, B.C., Fisher, W.E., Heslop, H.E., Rooney, C.M., Brenner, M.K., Leen, A.M., and Vera, J.F. (2014). Kinetics of tumor destruction by chimeric antigen receptor-modified T cells. Mol Ther 22, 623-633.

Barrett, D.M., Grupp, S.A., and June, C.H. (2015). Chimeric antigen receptor- and TCR-modified T cells enter main street and wall street. J Immunol 195, 755-761.

Barrett, D.M., Singh, N., Porter, D.L., Grupp, S.A., and June, C.H. (2014). Chimeric antigen receptor therapy for cancer. Annu Rev Med 65, 333-347.

Beavis, P.A., Slaney, C.Y., Kershaw, M.H., Neeson, P.J., and Darcy, P.K. (2015). Enhancing the efficacy of adoptive cellular therapy by targeting tumor-induced immunosuppression. Immunotherapy 7, 499-512.

Budde, L.E., Berger, C., Lin, Y., Wang, J., Lin, X., Frayo, S.E., Brouns, S.A., Spencer, D.M., Till, B.G., Jensen, M.C., Riddell, S.R., and Press, O.W. (2013). Combining a CD20 chimeric antigen receptor and an inducible caspase 9 suicide switch to improve the efficacy and safety of T cell adoptive immunotherapy for lymphoma. PLoS One 8, e82742.

Carpenito, C., Milone, M.C., Hassan, R., Simonet, J.C., Lakhal, M., Suhoski, M.M., Varela-Rohena, A., Haines, K.M., Heitjan, D.F., Albelda, S.M., Carroll, R.G., Riley, J.L., Pastan, I., and June, C.H. (2009). Control of large, established tumor xenografts with genetically retargeted human T cells containing CD28 and CD137 domains. Proc Natl Acad Sci USA 106, 3360-3365.

Caruana, I., Savoldo, B., Hoyos, V., Weber, G., Liu, H., Kim, E.S., Ittmann, M.M., Marchetti, D., and Dotti, G. (2015a). Heparanase promotes tumor infiltration and antitumor activity of CAR-redirected $\mathrm{T}$ lymphocytes. Nat Med 21, 524-529.

Caruana, I., Weber, G., Ballard, B.C., Wood, M.S., Savoldo, B., and Dotti, G. (2015b). K562-derived whole-cell vaccine enhances antitumor responses of CAR-redirected virus-specific cytotoxic T lymphocytes in vivo. Clin Cancer Res 21, 2952-2962.

Caruso, H.G., Hurton, L.V., Najjar, A., Rushworth, D., Ang, S., Olivares, S., Mi, T., Switzer, K., Singh, H., Huls, H., Lee, D.A., Heimberger, A.B., Champlin, R.E., and Cooper, L.J. (2015). Tuning sensitivity of CAR to EGFR density limits recognition of normal tissue while maintaining potent antitumor activity. Cancer Res 75, 3505-3518.

Cheadle, E.J., Gornall, H., Baldan, V., Hanson, V., Hawkins, R.E., and Gilham, D.E. (2014). CAR T cells: driving the road from the laboratory to the clinic. Immunol Rev 257, 91-106.

Chmielewski, M., and Abken, H. (2015). TRUCKs: the fourth generation of CARs. Expert Opin Biol Ther 15, 1145-1154.

Chmielewski, M., Hombach, A.A., and Abken, H. (2013). Antigen-specific T-cell activation independently of the MHC: chimeric antigen receptor-redirected T cells. Front Immunol 4, 371.

Chmielewski, M., Kopecky, C., Hombach, A.A., and Abken, H. (2011). IL-12 release by engineered $\mathrm{T}$ cells expressing chimeric antigen receptors can effectively Muster an antigen-independent macrophage response on tumor cells that have shut down tumor antigen expression. Cancer Res 71, 5697-5706.

Couzin-Frankel, J. (2015). CANCER IMMUNOTHERAPY. Baby's leukemia recedes after novel cell therapy. Science 350, 731.

Cruz, C.R. (2014). A closer look at chimeric antigen receptor specificity. Cytotherapy 16, 1323-1324.

Cruz, C.R., Micklethwaite, K.P., Savoldo, B., Ramos, C.A., Lam, S., Ku, S., Diouf, O., Liu, E., Barrett, A.J., Ito, S., Shpall, E.J., Krance, R.A., Kamble, R.T., Carrum, G., Hosing, C.M., Gee, A.P., Mei, Z., Grilley, B.J., Heslop, H.E., Rooney, C.M., Brenner, M.K., Bollard, C.M., and Dotti, G. (2013). Infusion of donor-derived CD19-redirected virus-specific $\mathrm{T}$ cells for B-cell malignancies relapsed after allogeneic stem cell transplant: a phase 1 study. Blood 122, 2965-2973.

Curran, K.J., Pegram, H.J., and Brentjens, R.J. (2012). Chimeric antigen receptors for $\mathrm{T}$ cell immunotherapy: current understanding and future directions. J Gene Med 14, 405-415.

Dai, H., Zhang, W., Li, X., Han, Q., Guo, Y., Zhang, Y., Wang, Y., Wang, C., Shi, F., Zhang, Y., Chen, M., Feng, K., Wang, Q., Zhu, H., Fu, X., Li, S., and Han, W. (2015). Tolerance and efficacy of autologous or 
donor-derived T cells expressing CD19 chimeric antigen receptors in adult B-ALL with extramedullary leukemia. Oncoimmunology 4, e1027469.

Davila, M.L., Riviere, I., Wang, X., Bartido, S., Park, J., Curran, K., Chung, S.S., Stefanski, J., Borquez-Ojeda, O., Olszewska, M., Qu, J., Wasielewska, T., He, Q., Fink, M., Shinglot, H., Youssif, M., Satter, M., Wang, Y., Hosey, J., Quintanilla, H., Halton, E., Bernal, Y., Bouhassira, D.C., Arcila, M.E., Gonen, M., Roboz, G.J., Maslak, P., Douer, D., Frattini, M.G., Giralt, S., Sadelain, M., and Brentjens, R. (2014). Efficacy and toxicity management of 19-28z CAR T cell therapy in B cell acute lymphoblastic leukemia. Sci Transl Med 6, $224 \mathrm{ra} 225$.

Deng, Z., Wu, Y., Ma, W., Zhang, S., and Zhang, Y.Q. (2015). Adoptive T-cell therapy of prostate cancer targeting the cancer stem cell antigen EpCAM. BMC Immunol 16, 1.

Deniger, D.C., Yu, J., Huls, M.H., Figliola, M.J., Mi, T., Maiti, S.N., Widhopf, G.F., 2nd, Hurton, L.V., Thokala, R., Singh, H., Olivares, S., Champlin, R.E., Wierda, W.G., Kipps, T.J., and Cooper, L.J. (2015). Sleeping beauty transposition of chimeric antigen receptors targeting receptor tyrosine kinase-like orphan receptor-1 (ROR1) into diverse memory T-cell populations. PLoS One 10, e0128151.

Enblad, G., Karlsson, H., and Loskog, A.S. (2015). CAR T-cell therapy: the role of physical barriers and immunosuppression in lymphoma. Human Gene ther 26, 498-505.

Fedorov, V.D., Themeli, M., and Sadelain, M. (2013). PD-1- and CTLA-4-based inhibitory chimeric antigen receptors (iCARs) divert off-target immunotherapy responses. Sci Transl Med 5, 215 ra172.

Finney, H.M., Akbar, A.N., and Lawson, A.D.G. (2003). Activation of resting human primary $\mathrm{T}$ cells with chimeric receptors: costimulation from CD28, inducible costimulator, CD134, and CD137 in series with signals from the TCR chain. J Immunol 172, 104-113.

Gajewski, T.F., Schreiber, H., and Fu, Y.X. (2013). Innate and adaptive immune cells in the tumor microenvironment. Nat Immunol 14, 1014-1022.

Gao, H., Li, K., Tu, H., Pan, X., Jiang, H., Shi, B., Kong, J., Wang, H., Yang, S., Gu, J., and Li, Z. (2014a). Development of T cells redirected to glypican-3 for the treatment of hepatocellular carcinoma. Clin Cancer Res 20, 6418-6428.

Gattinoni, L., Klebanoff, C.A., Palmer, D.C., Wrzesinski, C., Kerstann, K., Yu, Z., Finkelstein, S.E., Theoret, M.R., Rosenberg, S.A., and Restifo, N.P. (2005). Acquisition of full effector function in vitro paradoxically impairs the in vivo antitumor efficacy of adoptively transferred $\mathrm{CD} 8^{+} \mathrm{T}$ cells. J Clin Invest 115, 1616-1626.

Gattinoni, L., Lugli, E., Ji, Y., Pos, Z., Paulos, C.M., Quigley, M.F., Almeida, J.R., Gostick, E., Yu, Z., Carpenito, C., Wang, E., Douek, D.C., Price, D.A., June, C.H., Marincola, F.M., Roederer, M., and Restifo, N.P. (2011). A human memory T cell subset with stem cell-like properties. Nat Med 17, 1290-1297.

Gill, S., and June, C.H. (2015). Going viral: chimeric antigen receptor T-cell therapy for hematological malignancies. Immunol Rev 263, 68-89.

Gross, G., Gorochov, G., Waks, T., and Eshhar, Z. (1989). Generation of effector $\mathrm{T}$ cells expressing chimeric $\mathrm{T}$ cell receptor with antibody type-specificity. Transplant Proc 21, 127-130.

Guo, B., Chen, M., Han, Q., Hui, F., Dai, H., Zhang, W., Zhang, Y., Wang, Y., Zhu, H., and Han, W. (2015). CD138-directed adoptive immunotherapy of chimeric antigen receptor (CAR)-modified $\mathrm{T}$ cells for multiple myeloma. J Cell Immunother 61, 1-8.

Haynes, N.M., Snook, M.B., Trapani, J.A., Cerruti, L., Jane, S.M., Smyth, M.J., and Darcy, P.K. (2001). Redirecting mouse CTL against colon carcinoma: superior signaling efficacy of single-chain variable domain chimeras containing $\mathrm{TCR}^{-}$vs $\mathrm{FcRI}^{-}$. J Immunol 166, 182-187.

Hinrichs, C.S., Borman, Z.A., Gattinoni, L., Yu, Z., Burns, W.R., Huang, J., Klebanoff, C.A., Johnson, L.A., Kerkar, S.P., Yang, S., Muranski, P., Palmer, D.C., Scott, C.D., Morgan, R.A., Robbins, P.F., Rosenberg, S.A., and Restifo, N.P. (2011). Human effector CD8 ${ }^{+}$T cells derived from naive rather than memory subsets possess superior traits for adoptive immunotherapy. Blood 117, 808-814.
Hinrichs, C.S., and Restifo, N.P. (2013). Reassessing target antigens for adoptive T-cell therapy. Nat Biotechnol 31, 999-1008.

Hombach, A.A., Heiders, J., Foppe, M., Chmielewski, M., and Abken, H. (2012). OX40 costimulation by a chimeric antigen receptor abrogates CD28 and IL-2 induced IL-10 secretion by redirected $\mathrm{CD}^{+} \mathrm{T}$ cells. Oncoimmunology 1, 458-466.

Hoyos, V., Savoldo, B., Quintarelli, C., Mahendravada, A., Zhang, M., Vera, J., Heslop, H.E., Rooney, C.M., Brenner, M.K., and Dotti, G. (2010). Engineering CD19-specific T lymphocytes with interleukin-15 and a suicide gene to enhance their anti-lymphoma/leukemia effects and safety. Leukemia 24, 1160-1170.

Hudecek, M., Lupo-Stanghellini, M.T., Kosasih, P.L., Sommermeyer, D., Jensen, M.C., Rader, C., and Riddell, S.R. (2013). Receptor affinity and extracellular domain modifications affect tumor recognition by ROR1-specific chimeric antigen receptor T cells. Clin Cancer Res 19, 3153-3164.

John, L.B., Devaud, C., Duong, C.P., Yong, C.S., Beavis, P.A., Haynes, N.M., Chow, M.T., Smyth, M.J., Kershaw, M.H., and Darcy, P.K. (2013). Anti-PD-1 antibody therapy potently enhances the eradication of established tumors by gene-modified T cells. Clin Cancer Res 19, 5636-5646.

Johnson, L.A., Scholler, J., Ohkuri, T., Kosaka, A., Patel, P.R., McGettigan, S.E., Nace, A.K., Dentchev, T., Thekkat, P., Loew, A., Boesteanu, A.C., Cogdill, A.P., Chen, T., Fraietta, J.A., Kloss, C.C., Posey, A.D., Jr., Engels, B., Singh, R., Ezell, T., Idamakanti, N., Ramones, M.H., Li, N., Zhou, L., Plesa, G., Seykora, J.T., Okada, H., June, C.H., Brogdon, J.L., and Maus, M.V. (2015). Rational development and characterization of humanized anti-EGFR variant III chimeric antigen receptor T cells for glioblastoma. Sci Transl Med 7, $275 \mathrm{ra} 222$.

Joyce, J.A., and Fearon, D.T. (2015). T cell exclusion, immune privilege, and the tumor microenvironment. Science 348, 74-80.

Kakarla, S., and Gottschalk, S. (2014). CAR T cells for solid tumors: armed and ready to go? Cancer J 20, 151-155.

Kenderian, S.S., Ruella, M., Shestova, O., Klichinsky, M., Aikawa, V., Morrissette, J.J., Scholler, J., Song, D., Porter, D.L., Carroll, M., June, C.H., and Gill, S. (2015). CD33-specific chimeric antigen receptor T cells exhibit potent preclinical activity against human acute myeloid leukemia. Leukemia 29, 1637-1647.

Kloss, C.C., Condomines, M., Cartellieri, M., Bachmann, M., and Sadelain, M. (2013). Combinatorial antigen recognition with balanced signaling promotes selective tumor eradication by engineered $\mathrm{T}$ cells. Nat Biotechnol 31, 71-75

Krug, C., Wiesinger, M., Abken, H., Schuler-Thurner, B., Schuler, G., Dorrie, J., and Schaft, N. (2014). A GMP-compliant protocol to expand and transfect cancer patient $\mathrm{T}$ cells with mRNA encoding a tumor-specific chimeric antigen receptor. Cancer Immunol Immunother 63, 999-1008.

Lee, D.W., Gardner, R., Porter, D.L., Louis, C.U., Ahmed, N., Jensen, M., Grupp, S.A., and Mackall, C.L. (2014). Current concepts in the diagnosis and management of cytokine release syndrome. Blood 124, 188-195.

Lee, D.W., Kochenderfer, J.N., Stetler-Stevenson, M., Cui, Y.K., Delbrook, C., Feldman, S.A., Fry, T.J., Orentas, R., Sabatino, M., Shah, N.N., Steinberg, S.M., Stroncek, D., Tschernia, N., Yuan, C., Zhang, H., Zhang, L., Rosenberg, S.A., Wayne, A.S., and Mackall, C.L. (2015). T cells expressing CD19 chimeric antigen receptors for acute lymphoblastic leukaemia in children and young adults: a phase 1 dose-escalation trial. Lancet 385, 517-528.

Liu, K., Liu, X., Peng, Z., Sun, H., Zhang, M., Zhang, J., Liu, S., Hao, L., Lu, G., Zheng, K., Gong, X., Wu, D., Wang, F., and Shen, L. (2015a). Retargeted human avidin-CAR $\mathrm{T}$ cells for adoptive immunotherapy of EGFRvIII expressing gliomas and their evaluation via optical imaging. Oncotarget 6, 23735-23747.

Liu, X., Jiang, S., Fang, C., Yang, S., Olalere, D., Pequignot, E.C., Cogdill, A.P., Li, N., Ramones, M., Granda, B., Zhou, L., Loew, A., Young, R.M., June, C.H., and Zhao, Y. (2015b). Affinity-tuned ErbB2 or EGFR chimeric antigen receptor $\mathrm{T}$ cells exhibit an increased therapeutic index against tumors in mice. Cancer Res 75, 3596-3607. 
Long, A.H., Haso, W.M., Shern, J.F., Wanhainen, K.M., Murgai, M., Ingaramo, M., Smith, J.P., Walker, A.J., Kohler, M.E., Venkateshwara, V.R., Kaplan, R.N., Patterson, G.H., Fry, T.J., Orentas, R.J., and Mackall, C.L. (2015). 4-1BB costimulation ameliorates $\mathrm{T}$ cell exhaustion induced by tonic signaling of chimeric antigen receptors. Nat Med 21, 581-590.

Mahoney, K.M., Rennert, P.D., and Freeman, G.J. (2015). Combination cancer immunotherapy and new immunomodulatory targets. Nat Rev Drug Discov 14, 561-584.

Maude, S.L., Frey, N., Shaw, P.A., Aplenc, R., Barrett, D.M., Bunin, N.J., Chew, A., Gonzalez, V.E., Zheng, Z., Lacey, S.F., Mahnke, Y.D., Melenhorst, J.J., Rheingold, S.R., Shen, A., Teachey, D.T., Levine, B.L., June, C.H., Porter, D.L., and Grupp, S.A. (2014). Chimeric antigen receptor T cells for sustained remissions in leukemia. N Engl J Med 371, 1507-1517.

Maude, S.L., Teachey, D.T., Porter, D.L., and Grupp, S.A. (2015). CD19-targeted chimeric antigen receptor T-cell therapy for acute lymphoblastic leukemia. Blood 125, 4017-4023.

Molon, B., Ugel, S., Del Pozzo, F., Soldani, C., Zilio, S., Avella, D., De Palma, A., Mauri, P., Monegal, A., Rescigno, M., Savino, B., Colombo, P., Jonjic, N., Pecanic, S., Lazzarato, L., Fruttero, R., Gasco, A., Bronte, V., and Viola, A. (2011). Chemokine nitration prevents intratumoral infiltration of antigen-specific T cells. J Exp Med 208, 1949-1962.

Moon, E.K., Carpenito, C., Sun, J., Wang, L.C., Kapoor, V., Predina, J., Powell, D.J., Jr., Riley, J.L., June, C.H., and Albelda, S.M. (2011). Expression of a functional CCR2 receptor enhances tumor localization and tumor eradication by retargeted human $\mathrm{T}$ cells expressing a mesothelin-specific chimeric antibody receptor. Clin Cancer Res 17, 4719-4730.

Moon, E.K., Wang, L.C., Dolfi, D.V., Wilson, C.B., Ranganathan, R., Sun, J., Kapoor, V., Scholler, J., Pure, E., Milone, M.C., June, C.H., Riley, J.L., Wherry, E.J., and Albelda, S.M. (2014). Multifactorial T-cell hypofunction that is reversible can limit the efficacy of chimeric antigen receptor-transduced human T cells in solid tumors. Clin Cancer Res 20, 4262-4273.

Morgan, R.A., Johnson, L.A., Davis, J.L., Zheng, Z., Woolard, K.D., Reap, E.A., Feldman, S.A., Chinnasamy, N., Kuan, C.T., Song, H., Zhang, W., Fine, H.A., and Rosenberg, S.A. (2012). Recognition of glioma stem cells by genetically modified $\mathrm{T}$ cells targeting EGFRvIII and development of adoptive cell therapy for glioma. Human Gene Ther 23, 1043-1053.

Morgan, R.A., and Kakarla, S. (2014). Genetic modification of T cells. Cancer J 20, 145-150.

Nakazawa, Y., Huye, L.E., Salsman, V.S., Leen, A.M., Ahmed, N., Rollins, L., Dotti, G., Gottschalk, S.M., Wilson, M.H., and Rooney, C.M. (2011). PiggyBac-mediated cancer immunotherapy using EBV-specific cytotoxic T-cells expressing HER2-specific chimeric antigen receptor. Mol Ther 19, 2133-2143.

Ninomiya, S., Narala, N., Huye, L., Yagyu, S., Savoldo, B., Dotti, G., Heslop, H.E., Brenner, M.K., Rooney, C.M., and Ramos, C.A. (2015). Tumor indoleamine 2,3-dioxygenase (IDO) inhibits CD19-CAR T cells and is downregulated by lymphodepleting drugs. Blood 125 , 3905-3916.

Oren, R., Hod-Marco, M., Haus-Cohen, M., Thomas, S., Blat, D., Duvshani, N., Denkberg, G., Elbaz, Y., Benchetrit, F., Eshhar, Z., Stauss, H., and Reiter, Y. (2014). Functional comparison of engineered $\mathrm{T}$ cells carrying a native TCR versus TCR-like antibody-based chimeric antigen receptors indicates affinity/avidity thresholds. J Immunol 193, 5733-5743.

Perna, S.K., Pagliara, D., Mahendravada, A., Liu, H., Brenner, M.K., Savoldo, B., and Dotti, G. (2014). Interleukin-7 mediates selective expansion of tumor-redirected cytotoxic T lymphocytes (CTLs) without enhancement of regulatory T-cell inhibition. Clin Cancer Res 20, 131-139.

Poirot, L., Philip, B., Schiffer-Mannioui, C., Le Clerre, D., Chion-Sotinel, I., Derniame, S., Potrel, P., Bas, C., Lemaire, L., Galetto, R., Lebuhotel, C., Eyquem, J., Cheung, G.W., Duclert, A., Gouble, A., Arnould, S., Peggs, K., Pule, M., Scharenberg, A.M., and Smith, J. (2015b).
Multiplex Genome-Edited T-cell Manufacturing Platform for "Off-the-Shelf" Adoptive T-cell Immunotherapies. Cancer research.

Porter, D.L., Hwang, W.T., Frey, N.V., Lacey, S.F., Shaw, P.A., Loren, A.W., Bagg, A., Marcucci, K.T., Shen, A., Gonzalez, V., Ambrose, D., Grupp, S.A., Chew, A., Zheng, Z., Milone, M.C., Levine, B.L., Melenhorst, J.J., and June, C.H. (2015). Chimeric antigen receptor T cells persist and induce sustained remissions in relapsed refractory chronic lymphocytic leukemia. Sci Transl Med 7, 303ra139.

Pule, M.A., Savoldo, B., Myers, G.D., Rossig, C., Russell, H.V., Dotti, G., Huls, M.H., Liu, E., Gee, A.P., Mei, Z., Yvon, E., Weiss, H.L., Liu, H., Rooney, C.M., Heslop, H.E., and Brenner, M.K. (2008). Virus-specific $\mathrm{T}$ cells engineered to coexpress tumor-specific receptors: persistence and antitumor activity in individuals with neuroblastoma. Nat Med 14, 1264-1270.

Ramanayake, S., Bilmon, I., Bishop, D., Dubosq, M.C., Blyth, E., Clancy, L., Gottlieb, D., and Micklethwaite, K. (2015). Low-cost generation of good manufacturing practice-grade CD19-specific chimeric antigen receptor-expressing $\mathrm{T}$ cells using piggyBac gene transfer and patient-derived materials. Cytotherapy 17, 1251-1267.

Rosenberg, S.A., and Restifo, N.P. (2015). Adoptive cell transfer as personalized immunotherapy for human cancer. Science 348, 62-68.

Sadelain, M. (2015). CAR therapy: the CD19 paradigm. J Clin Invest 125, 3392-3400

Sadelain, M., Brentjens, R., and Riviere, I. (2013). The basic principles of chimeric antigen receptor design. Cancer Discov 3, 388-398.

Shen, C.J., Yang, Y.X., Han, E.Q., Cao, N., Wang, Y.F., Wang, Y., Zhao, Y.Y., Zhao, L.M., Cui, J., Gupta, P., Wong, A.J., and Han, S.Y. (2013). Chimeric antigen receptor containing ICOS signaling domain mediates specific and efficient antitumor effect of $\mathrm{T}$ cells against EGFRvIII expressing glioma. J Hematol Oncol 6, 33.

Singh, H., Figliola, M.J., Dawson, M.J., Huls, H., Olivares, S., Switzer, K., Mi, T., Maiti, S., Kebriaei, P., Lee, D.A., Champlin, R.E., and Cooper, L.J. (2011). Reprogramming CD19-specific T cells with IL-21 signaling can improve adoptive immunotherapy of B-lineage malignancies. Cancer Res 71, 3516-3527.

Singh, H., Moyes, J.S., Huls, M.H., and Cooper, L.J. (2015). Manufacture of $\mathrm{T}$ cells using the sleeping beauty system to enforce expression of a CD19-specific chimeric antigen receptor. Cancer Gene Ther 22, 95-100.

Song, D.G., Ye, Q., Carpenito, C., Poussin, M., Wang, L.P., Ji, C., Figini, M., June, C.H., Coukos, G., and Powell, D.J., Jr. (2011). In vivo persistence, tumor localization, and antitumor activity of CAR-engineered $\mathrm{T}$ cells is enhanced by costimulatory signaling through CD137 (4-1BB). Cancer Res 71, 4617-4627.

Song, D.G., Ye, Q., Poussin, M., Harms, G.M., Figini, M., and Powell, D.J., Jr. (2012). CD27 costimulation augments the survival and antitumor activity of redirected human $\mathrm{T}$ cells in vivo. Blood 119, 696-706.

Song, D.G., Ye, Q., Poussin, M., Liu, L., Figini, M., and Powell, D.J., Jr. (2015). A fully human chimeric antigen receptor with potent activity against cancer cells but reduced risk for off-tumor toxicity. Oncotarget 6, 21533-21546.

Srivastava, S., and Riddell, S.R. (2015). Engineering CAR-T cells: design concepts. Trends Immunol 36, 494-502.

Tan, K.W., Evrard, M., Tham, M., Hong, M., Huang, C., Kato, M., Prevost-Blondel, A., Donnadieu, E., Ng, L.G., and Abastado, J.P. (2015). Tumor stroma and chemokines control T-cell migration into melanoma following Temozolomide treatment. Oncoimmunology 4, e978709.

Tang, X., Zhou, Y., Li, W., Tang, Q., Chen, R., Zhu, J., and Feng, Z. (2014). T cells expressing a LMP1-specific chimeric antigen receptor mediate antitumor effects against LMP1-positive nasopharyngeal carcinoma cells in vitro and in vivo. J Biomed Res 28, 468-475.

Terakura, S., Yamamoto, T.N., Gardner, R.A., Turtle, C.J., Jensen, M.C., and Riddell, S.R. (2012). Generation of CD19-chimeric antigen receptor modified $\mathrm{CD}^{+} \mathrm{T}$ cells derived from virus-specific central memory T cells. Blood 119, 72-82.

Turtle, C.J. (2013). Chimeric antigen receptor modified T cell therapy for B cell malignancies. Int J Hematol 99, 132-140. 
Valton, J., Guyot, V., Marechal, A., Filhol, J.M., Juillerat, A., Duclert, A., Duchateau, P., and Poirot, L. (2015). A multidrug-resistant engineered CAR T cell for allogeneic combination immunotherapy. Mol Ther 23, $1507-1518$.

van der Stegen, S.J.C., Hamieh, M., and Sadelain, M. (2015). The pharmacology of second-generation chimeric antigen receptors. Nat Rev Drug Discov 14, 499-509.

van der Waart, A.B., Hobo, W., and Dolstra, H. (2015). Time to: superior tumor-reactive $\mathrm{T}$ cells for adoptive immunotherapy. Oncoimmunology 4, e1003016.

van der Waart, A.B., van de Weem, N.M., Maas, F., Kramer, C.S., Kester, M.G., Falkenburg, J.H., Schaap, N., Jansen, J.H., van der Voort, R., Gattinoni, L., Hobo, W., and Dolstra, H. (2014). Inhibition of Akt signaling promotes the generation of superior tumor-reactive $\mathrm{T}$ cells for adoptive immunotherapy. Blood 124, 3490-3500.

Wang, C., Hu, W., Shen, L., Dou, R., Zhao, S., Shan, D., Yu, K., Huang, R., and Li, H. (2014a). Adoptive antitumor immunotherapy in vitro and in vivo using genetically activated erbB2-specific T cells. J Immunother 37, 351-359.

Wang, D., Zhang, L., Li, Y., Wang, H., Xiao, Q., Cao, W., and Feng, W. (2012a). Construction and expression of humanized chimeric T cell receptor specific for chronic myeloid leukemia cells. Biotechnol Lett 34, 1193-1201

Wang, Q.S., Wang, Y., Lv, H.Y., Han, Q.W., Fan, H., Guo, B., Wang, L.L., and Han, W.D. (2015). Treatment of CD33-directed chimeric antigen receptor-modified $\mathrm{T}$ cells in one patient with relapsed and refractory acute myeloid leukemia. Mol Ther 23, 184-191.

Wang, W., Ma, Y., Li, J., Shi, H.S., Wang, L.Q., Guo, F.C., Zhang, J., Li, D., Mo, B.H., Wen, F., Liu, T., Liu, Y.T., Wang, Y.S., and Wei, Y.Q. (2013). Specificity redirection by CAR with human VEGFR-1 affinity endows T lymphocytes with tumor-killing ability and anti-angiogenic potency. Gene Ther 20, 970-978.

Wang, X., Naranjo, A., Brown, C.E., Bautista, C., Wong, C.W., Chang, W.C., Aguilar, B., Ostberg, J.R., Riddell, S.R., Forman, S.J., and Jensen, M.C. (2012c). Phenotypic and functional attributes of lentivirusmodified CD19-specific human $\mathrm{CD}^{+}$central memory $\mathrm{T}$ cells manufactured at clinical scale. J Immunother 35, 689-701.
Wang, Y., Zhang, W.Y., Han, Q.W., Liu, Y., Dai, H.R., Guo, Y.L., Bo, J., Fan, H., Zhang, Y., Zhang, Y.J., Chen, M.X., Feng, K.C., Wang, Q.S., Fu, X.B., and Han, W.D. (2014d). Effective response and delayed toxicities of refractory advanced diffuse large B-cell lymphoma treated by $\mathrm{CD} 20$-directed chimeric antigen receptor-modified $\mathrm{T}$ cells. Clin Immunol 155, 160-175.

Weibo, P., and Zhaoming, Y. (2012). Auto T cells expressing chimeric antigen receptor derived from auto antibody might be a new treatment for osteosarcoma. Med Hypotheses 78, 616-618.

Wu, C.Y., Roybal, K.T., Puchner, E.M., Onuffer, J., and Lim, W.A. (2015a). Remote control of therapeutic $T$ cells through a small molecule-gated chimeric receptor. Science 350, aab4077.

Wu, Y., Deng, Z., Tang, Y., Zhang, S., and Zhang, Y.Q. (2015b). Over-expressing Akt in T cells to resist tumor immunosuppression and increase anti-tumor activity. BMC Cancer 15, 603.

Xu, Y., Zhang, M., Ramos, C.A., Durett, A., Liu, E., Dakhova, O., Liu, H., Creighton, C.J., Gee, A.P., Heslop, H.E., Rooney, C.M., Savoldo, B., and Dotti, G. (2014). Closely related T-memory stem cells correlate with in vivo expansion of CAR.CD19-T cells and are preserved by IL-7 and IL-15. Blood 123, 3750-3759.

Yang, Y. (2015). Cancer immunotherapy: harnessing the immune system to battle cancer. J Clin Invest 125, 3335-3337.

Zhao, Q., Ahmed, M., Tassev, D.V., Hasan, A., Kuo, T.Y., Guo, H.F., O'Reilly, R.J., and Cheung, N.K. (2015a). Affinity maturation of T-cell receptor-like antibodies for Wilms tumor 1 peptide greatly enhances therapeutic potential. Leukemia 29, 2238-2247.

Zhao, Z., Condomines, M., van der Stegen, S.J., Perna, F., Kloss, C.C., Gunset, G., Plotkin, J., and Sadelain, M. (2015b). Structural design of engineered costimulation determines tumor rejection kinetics and persistence of CAR T cells. Cancer Cell 28, 415-428.

Zheng, Y., Yu, K., Du, J., Jiang, L., Zhang, S., Han, Y., Yu, P., and Tan, Y. (2010). Potential therapeutic strategy for non-Hodgkin lymphoma by anti-CD20scFvFc/CD28/CD3zeta gene tranfected T cells. J Exp Clin Cancer Res 29, 121.

Zhou, X., Li, J., Wang, Z., Chen, Z., Qiu, J., Zhang, Y., Wang, W., Ma, Y., Huang, N., Cui, K., Li, J., and Wei, Y.-Q. (2013). Cellular immunotherapy for carcinoma using genetically modified EGFR-specific T lymphocytes. Neoplasia 15, 544-IN521.

Open Access This article is distributed under the terms of the Creative Commons Attribution License which permits any use, distribution, and reproduction in any medium, provided the original author(s) and source are credited. 